\title{
Analysis of Trade Diversion Effect Under Sino-us Trade Friction - - Taking Developing Countries and Developed Countries As Examples
}

\author{
Deng Chuang, ${ }^{1}{ }^{*}$ \\ ${ }^{1}$ China Jiliang University, International Business, Hangzhou, China
}

\begin{abstract}
Under the background of sino-us trade friction, what kind of trade diversion effect will china produce to the third country market. Based on the monthly import and export data of China and its 11 major trading partners from January 2014 to December 2019, this paper analyzes the trade diversion of sino-us trade frictions to China's neighboring countries by using the double-difference and panel quantile methods, and through the selection of developing countries and developed countries as a control group for the spillover effects of trade transfer analysis. Empirical analysis: under the background of China's trade frictions, China's imports and exports to the United States have been significantly negatively affected, the trade conflict between China and the United States has a significant trade diversion effect on the third country, and the spillover effect on the developing country is larger and longer-term than that on the developed country.
\end{abstract}

\section{Introduction}

By the end of October 2019, China and the United States had exchanged tariffs for more than six rounds, and China and the United States have fought many rounds of trade wars. Under the agreement between the two countries, the tariffs of the two countries have not been substantially reduced, and are significantly higher than before the trade agreement. In recent years, the trade cooperation between China and ASEAN has been deepening rapidly and its potential has been continuously released. In 2018, against the backdrop of trade frictions between China and the United States, the interdependence among the EU, the United States and ASEAN, China's major import and export trading partners, has deepened, and China's economic interdependence with the world has deepened.

China's exports are going to the EU and ASEAN, while the US is moving more to countries in the Americas such as Canada, Mexico and Brazil. Trade diversion effect, that is, trade friction between China and the United States will increase the import and export volume of third countries. The main reasons are twofold: first, when trade frictions occur between China and the United States, the United States takes various forms of restraint against Chinese products, such as imposing high tariffs, implementing technical barriers, and sanctioning Chinese high-tech enterprises, it will lower the cost of products from third countries, increase the competitiveness of products from non-trade friction countries, and put products from China at a relative price disadvantage.

\section{Literature Review}

Scholars at home and abroad have made extensive academic discussions on the issue of sino-us trade friction. At the macro level, ${ }^{[1]}$ Guo Qing and Gilbert Chan (2019) analyze the welfare impact of bilateral trade policies on major global trading partners based on a general equilibrium numerical model, impact on economic growth, employment, and well-being in China and the United States. From the perspective of value-added trade, ${ }^{[2]} \mathrm{Xiao}$ Zhimin and Feng Shenghao (2019) use the GTAP scenario to analyze the impact of China's exports on U.S. exports under trade friction. ${ }^{[3]} \mathrm{Lv}$ Yue and Lou Chengrong (2019) use WITS-SMART model to analyze the trade friction between China and the United States on the impact of trade and welfare effects are negative. The conclusion of their analysis is basically the same. At the micro level, ${ }^{[4]}$ Cao Ping and Xiao Shengpeng (2021) used multi-phase DID to analyze that American anti-dumpingwould restrain Chinese Enterprises'innovation.

This paper starts from the following two aspects. First, we use the data of sino-us trade conflict to analyze the impact of sino-us trade friction on China The second is to analyze the trade diversion effect of trade friction on asean and eu countries through country heterogeneity. Therefore, this article from the developed and developing countries tries to explain the following issues. For example, in the course of the trade game between big countries, is there a "profit-taking"or a "collateral damage"phenomenon among small countries? 


\section{Research methods and model design}

\subsection{Trade Diversion Effect}

This paper uses Broewn \& Crowley (2007)'s oligopoly competition model to analyze the trade diversion effect to the third country under the background of trade friction, and uses Carter \& Steinbach (2018)'s derivation process for reference, the paper uses the idea of oligarch competition to demonstrate the trade diversion effect brought by trade friction and the country heterogeneity. Suppose that there are only three countries $I, j \in\{A, B$, c \}, I $\neq \mathrm{J}$, each country has only one manufacturer I or J, using M"ij"to denote I company exporting to J Country, the former I company, the latter J country exporting to $\mathrm{J}$ country; domestic output is represented by $\mathrm{M}$, which is the product produced by the company for domestic use. Let's say it's an oligopoly, the competitors have the same level of technology, the only three companies are competing against each other, the products are substituting for each other, and the domestic consumer has no difference between foreign and domestic products, $(\pi \mathrm{m})$ means that domestic and foreign firms are competing with each other, the total output of the firm is equal to the sum of domestic supply and exports, $q \sum j$ something $m, j \in(A, B, c)$, the inverse demand function $\mathrm{p}(\mathrm{Q} i, \mathrm{Yi})$ that each firm faces, and then according to the firm's profit maximization:

$$
\max _{i}=\left[\sum_{j} \mathrm{P}(\mathrm{Qi}, \mathrm{Yi}) m_{i j}-\omega_{i j} m_{i j}\right]-c\left(Q_{i}\right)
$$

$\mathrm{C}(\mathrm{Q})$ is the cost function of country I production, $\omega$ is the tariff cost, $\mathrm{j} \in\{\mathrm{A}, \mathrm{B}, \mathrm{c}\}$, total profit is the total income minus the tariff part and the production cost, in order to get the profit maximization, we should choose the appropriate output Qi.

Suppose that when country a levies a tariff, the firstorder condition of the maximum value is 0 .

$$
\frac{\partial \pi_{i}}{\partial m_{i j}}=\sum_{j} \mathrm{P}(\mathrm{Qi}, \mathrm{Yi})-\omega_{i j}-c(Q)_{i}^{\prime}
$$

$\mathrm{J} \in\{\mathrm{A}, \mathrm{B}, \mathrm{C}\}$, we obtain the output level of firm I when tariff is imposed by country $A$, and then we obtain the equilibrium solution of firm $\mathrm{I} \in\{\mathrm{A}, \mathrm{B}, \mathrm{C}\}$. We solve the above equations and obtain the Charles Gounod-nash equilibrium output of each firm. The quantity function of the foreign market is $\mathrm{m}(\mathrm{Qi}, \mathrm{Yi}), \mathrm{c}(\mathrm{Q}), \omega)$, and the demand function of the foreign market is closely related to the domestic tariff, as well as the production cost, each firm must reallocate its market share in each country, or trade transfer.

\subsection{Model Building}

In April 2018, the United States announced the launch of the " 301 "survey and the announcement of a $\$ 50$ billion tariff list, setting the time before the tariff increase to zero and the time after the tariff increase to one. ${ }^{[5]}$ This article considers April 2018 and later as a period for levying additional tariffs on two grounds: one is limited to the availability of tariffs, which, because of the wide variety of products involved, do not have precise rates; the other is ad valorem and specific duty on the list of levies, in the conversion process inevitable error.

Among them, the explanatory variable lnexit is the value of China's exports to the exporting country I in $\mathrm{T}$ period, and LNIMIT is the value of China's imports to the exporting country $\mathrm{I}$ in $\mathrm{T}$ period, post is a virtual variable to distinguish the trade friction between China and the United States, 0 before the trade friction between China and the United States, 1 after the trade friction between China and the United States; Treatmenti * postt is the interaction between the group virtual variable and the policy implementation virtual variable, which reflects the net effect of sino-us trade friction implementation.

In this model, $\sum X \mathrm{XI}$ is a control variable other than trade friction. The gravity model is usually used to study trade flows between economies. The GDP of two economies is positively correlated to GDP (LNGDP), and negatively correlated to distance. With the expansion of gravity into exchange rate, cost, language and cultural factors. Based on the availability of monthly data and the factors influencing the trade volume of the two countries as well as the exchange rate of the two countries, we select the logarithm of the exchange rate (rate) between the trading partners and the US dollar, and the trade between the two countries is also affected by the price of the exports, therefore, the consumer price index (CPI) is chosen as the control variable. According to the model, before and after the sino-us trade conflict, China's exports to the control group (treatment $=0$ ) were as follows:

$$
\text { lnex }_{i t}=\left\{\begin{array}{c}
\alpha+\sum X_{i t}+\varepsilon_{i t}, \text { Before trade frictions } \\
\alpha+\alpha_{2}+\sum X_{i t}+\varepsilon_{i t}, \text { After trade friction }
\end{array}\right.
$$

Around the time of the sino-us trade conflict, China's exports to the treatment $=1$ countries were:

$$
\text { lnex }_{i t}=\left\{\begin{aligned}
\alpha+\alpha_{1}+\sum X_{i t}+\varepsilon_{i t}, & \text { Before trade frictions } \\
\alpha+\alpha_{1}+\alpha_{2}+\alpha_{3}+\sum X_{i t}+\varepsilon_{i t}, & \text { After trade friction }
\end{aligned}\right.
$$

The basic idea of the double difference method is to construct the double difference statistic which reflects the effect of the policy by comparing the difference between the control group and the treatment group before and after the implementation of the policy, and get the net effect of the policy under DID. At the same time, two conditions are needed to satisfy the double difference: first, the control group is not affected by the policy variables, and second, the other control variables should be the same except the implementation factors of the policy variables.

This article uses monthly data from January 2014 to December 2019, ranking China's imports and exports to all trading partners in 2019 before and after the shock, the final control group was selected as a control group of countries with similar economic structure to China, having selected the top 11 countries in 2019 in terms of volume of imports and exports to China, including India, the Russian Federation, Brazil, Indonesia, Thailand, Malaysia and Australia, the Philippines, Vietnam, the Netherlands, Singapore and 11 other countries. 
Table 1. Top 10 countries in China's import and export volume in 2019 (US billion).

\begin{tabular}{|c|c|c|}
\hline Partners & $\begin{array}{c}\text { Imports and } \\
\text { exports }\end{array}$ & Proportion \\
\hline JPN & 3150.33 & $6.88 \%$ \\
\hline KOR & 2845.76 & $6.21 \%$ \\
\hline DEU & 1848.82 & $4.04 \%$ \\
\hline AUS & 1696.36 & $3.70 \%$ \\
\hline VNM & 1620.04 & $3.54 \%$ \\
\hline MSY & 1239.62 & $2.70 \%$ \\
\hline RUS & 1107.94 & $2.42 \%$ \\
\hline India & 928.15 & $2.02 \%$ \\
\hline SGP & 899.41 & $1.96 \%$ \\
\hline NLD & 851.63 & $1.86 \%$ \\
\hline PHL & 609.52 & $1.33 \%$ \\
\hline
\end{tabular}

\subsection{Sample, data description and variable description}

\subsubsection{Sample and data description.}

This paper selects the monthly import and export data of China and 11 major trading countries from January 2014 to December 2019 to explain the trade diversion effect. The CPI comes from the IMF and is interpreted as China's imports and exports from other countries from China's monthly customs statistics; each country's GDP figures are quarterly, through the use of moving average method for quarterly data processing to obtain monthly data, and logarithmic processing to reduce the impact of variance.

\subsubsection{Control variables}

This paper chooses sino-us trade friction as the explanatory variable and controls other variables. Through the analysis of the impact on imports and exports, using consumer price index, GPD, exchange rate as control variables to explain the impact on imports and exports. In order to eliminate the effect of large variance, we use the logarithm of exchange rate and GDP for reference.

\section{Empirical analysis}

\subsection{Parallel trend test}

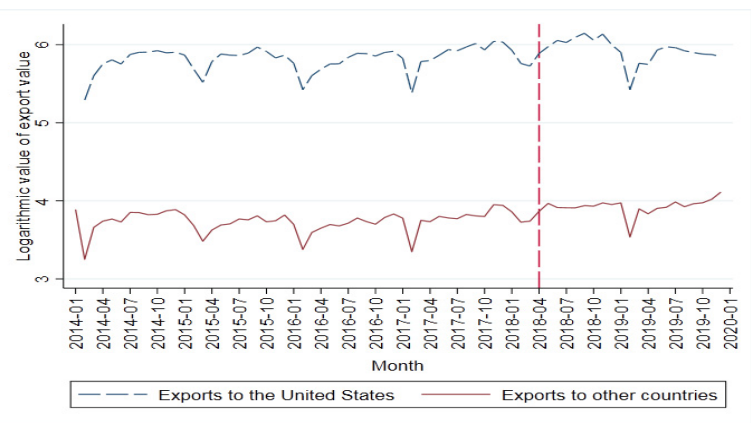

Fig. 1. Changes in China's exports from control and treatment groups before and after trade conflicts.

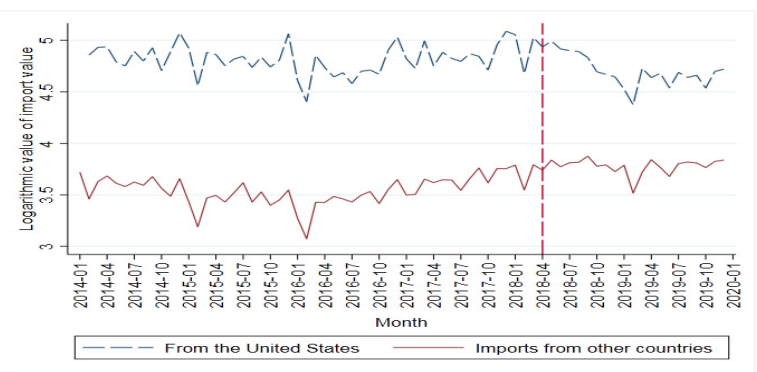

Fig. 2. changes of China's import from control group and treatment group before and after trade conflict.

Therefore, the trade volume between China and two groups of countries before and after the trade conflict is calculated first. According to the monthly customs data, as shown in figures 1 and 2, the straight line perpendicular to the horizontal axis is the cut-off point for sino-us friction (April 2018), and before the impact of the trade conflict, the trends in the volume of exports and imports of the control group and the processing group were basically the same, after the trade conflict between China and the United States, China's imports from the United States first showed a slight increase and then a big decrease. On the contrary, China's exports to the control group showed a small decrease and went through a period of steady growth, and then it dropped dramatically. The difference between the two lines is obviously reduced and the previous shape is not maintained, which shows that the double difference method is reasonable.

\subsection{Benchmark regression}

Table 2. Fixed effect regression (FE) regression on trade volume.

\begin{tabular}{|c|c|c|c|c|c|c|c|c|}
\hline \multirow{2}{*}{ Variable } & \multicolumn{9}{|c|}{ Inex } & \multicolumn{3}{|c|}{$\ln$} \\
\cline { 2 - 9 } & $\mathbf{1}$ & $\mathbf{2}$ & $\mathbf{3}$ & $\mathbf{4}$ & $\mathbf{5}$ & $\mathbf{6}$ & $\mathbf{7}$ & $\mathbf{8}$ \\
\hline \multirow{3}{*}{$\operatorname{did}$} & $-0.072^{* * *}$ & $-0.088^{* * *}$ & $-0.075^{* * *}$ & $-0.075^{* * *}$ & $-0.345^{* * *}$ & $-0.342^{* * *}$ & $-0.322^{* * *}$ & $-0.327 * * *$ \\
\cline { 2 - 9 } & $(-3.13)$ & $(-3.41)$ & $(-3.20)$ & $(-3.31)$ & $(-7.54)$ & $(-7.83)$ & $(-9.39)$ & $(-10.14)$ \\
\cline { 2 - 9 } & & & $(1.54)$ & $(0.93)$ & & & $(1.60)$ & $(-0.22)$ \\
\hline Time FE & YES & YES & YES & YES & YES & YES & YES & YES \\
\hline Country FE & YES & YES & YES & YES & YES & YES & YES & YES \\
\hline
\end{tabular}

After the dual fixed effect of country and time, the interaction item has a significant negative effect on both China's import and export. As can be seen from columns (5) to (8) of Table 2, sino-us trade frictions had a negative impact on China's imports from the US, but this impact was strongest when no other variables were included, at $34.5 \%$. In addition to GDP, exchange rate and CPI control variables, the impact on imports gradually weakened. Table 2(1) to (4) shows the impact of the sino-us trade conflict on China's exports. As expected, the sino-us trade 
conflict has a negative impact on China's exports to the United States. As shown in (5), the trade conflict resulted in a significant $7.2 \%$ reduction in China's exports to the United States. At the same time As a result, trade friction between China and the United States has a negative impact on China's import and export, and the impact of trade conflict on import is greater than that on export.

\subsection{Multiple regression}

Figure 3 measures the dynamic impact of trade conflicts in the 1-12 months following their onset. From the point of view of imports, China's exports are better than the average negative impact of 1-4 months after trade friction, showing a lag of 1-4 months.

China's imports are affected by trade friction, which is consistent with the conclusion drawn from the previous benchmark regression. The blocking of imports is not conducive to China's introduction of advanced technology and talents from the United States, it has a great restraining effect on the industrial transformation of our country. From the chart of the impact of trade conflict events on the dynamics of exports, the overall pattern of imports and exports is a "U"shape. After several months of policy expectations, China's imports and exports have dropped sharply. After a year of policy digestion, china's imports and exports have rebounded. Imports recovered better than exports. The possible reasons are: first, after the occurrence of trade frictions, China's imports are diverted to other countries, such as ASEAN and EU countries; second, at the same time, exports are more difficult to adjust than imports.

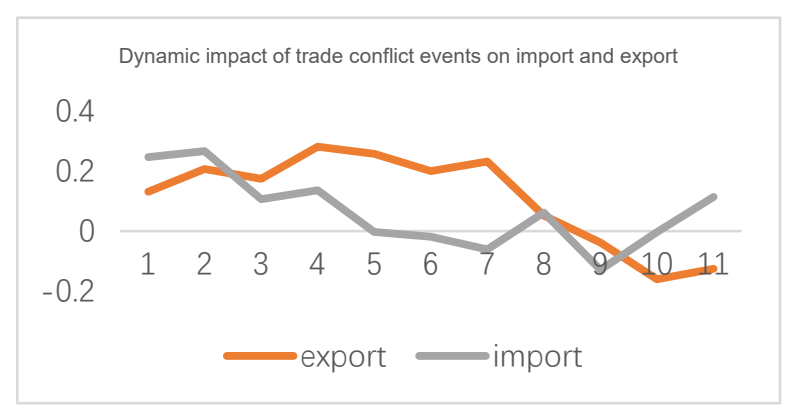

Figure 3. Dynamic impact of trade conflicts on imports and exports

\subsection{Placebo test}

In this study, the placebo test was used to test the effectiveness of the policy by advancing the time of the policy to eliminate the interference of other factors. To rule out such factors, we moved the month forward, and if the interaction variable becomes significantly negative at this point, then economic development is likely to come from other policy changes or random factors, rather than from a Sino US trade conflict. If the interaction item is not significantly negative at this time, it is due to sino-us trade friction. when China's trade policy is brought forward one year, the coefficients of the cross-product items are not significant whether the logarithmic value of the import value or the logarithmic value of the export value are taken as explanatory variables, indicating that only after the sino-us trade friction, china's total imports and exports have been affected by trade frictions.

\subsection{Analysis of heterogeneity}

When there is trade friction between the two countries, it will have a trade diversion effect on the market of the third country, using China's imports to other countries as an explanatory variable, the paper analyzes the trade diversion effect of 11 major import source countries of China. The model is constructed as follows:

$$
\operatorname{lnim}_{\text {it }}=\text { time }_{t}+\operatorname{lncgdp} p_{t}+\text { lnrate }_{t}+\varphi_{i t}
$$

Where LNIMIT is the logarithmic value of China's import trade volume from I country (region) in T period, I is the country, $\mathrm{T}$ is the period. LNCGDPT is the logarithmic value of China's monthly GDP data from January 2014 to December 2019, obtained by monthly processing of the quarterly data; crate is the exchange rate of the US dollar to the RMB; timet is the dummy variable representing the sino-us trade frictions, the month before April 2018 has a value of 1 and the month after that has a value of 1 .

The Hausman test uses the fixation effect. According to the World Bank's classification of developing and developed countries, the control group was divided into developing and developed countries. A sample of Chinese imports minus the US is divided into developing countries as follows: Thailand, indonesia, India, Russia, Brazil, the Philippines (which competes with China's economic structure) and developed countries (SouthKorea, Japan, Germany, the Netherlands, Australia and Singapore) return, considering that the impact of conflict events may have a dynamic effect, considering the dynamic effect of sino-us trade frictions, and reviewing the dynamics and persistence of trade frictions at different times, this paper selects three months (Post3) and six months (Post6) after sino-us trade as dynamic effects, and regresses the results as shown in Table 3.

Table 3. Analysis of country heterogeneity of trade transfer.

\begin{tabular}{|c|c|c|c|c|c|c|}
\hline \multirow{2}{*}{ Variable } & \multicolumn{3}{|c|}{ Developing countries } & \multicolumn{3}{c|}{ Developed countries } \\
\cline { 2 - 7 } & $(\mathbf{1})$ & $\mathbf{( 2 )}$ & $\mathbf{( 3 )}$ & $\mathbf{( 4 )}$ & $\mathbf{( 5 )}$ & $\mathbf{( 6 )}$ \\
\hline \multirow{2}{*}{ post1 } & $0.180^{* * *}$ & & & $0.065^{* * *}$ & & \\
\cline { 2 - 7 } & $(5.99)$ & & & $(2.80)$ & & \\
\hline \multirow{2}{*}{ post3 } & & $0.161^{* * *}$ & & & $0.055^{* * *}$ & \\
\cline { 2 - 7 } & & $(5.19)$ & & & $(2.34)$ & \\
\hline \multirow{2}{*}{ post6 } & & & $0.123^{* * *}$ & & & 0.028 \\
\cline { 2 - 7 } & & & $(3.93)$ & & & $(1.17)$ \\
\hline Time FE & YES & YES & YES & YES & YES & YES \\
\hline
\end{tabular}


From the results of Table 3 we can see that the sino-us trade conflict has obvious trade creation effect on both developing and developed countries, but the coefficient of trade diversion effect shows that the developing countries are bigger than the developed countries. The trade substitution effect of developing countries gradually weakened from 18 percent to 12.3 percent in the first month, and gradually weakened over time but had a longterm effect. The coefficients for developed countries from 6.5 percent at the time of trade to the sixth month were not significant, indicating a short-term effect in developed countries. Therefore, as the most important participants in the world economic system, the trade friction between China and the United States is bound to have a trade diversion effect on the third country. Based on the heterogeneous regression analysis, it is concluded that the developing countries will benefit from the sino-us trade friction in the long run.

\subsection{Panel quantile regression}

According to the heterogeneity of different countries, the quantile regression method is used to estimate the parameters. By combining the quantile with panel data, the effects of different quantiles on panel data were estimated, and the marginal effects of independent variables in different quantiles on dependent variables could be analyzed under the premise of controlling individual heterogeneity, that is, the trade diversion effect of sino-us trade friction on different countries. The use of panel quantile regression can make the variables more significant and better distinguish the impact of trade frictions on developing and developed countries. The fixed-effect model for the control individual was designed as follows:

$$
\begin{aligned}
& \operatorname{lnex}_{i t}^{\tau}\left(\tau \mid x_{i t}\right)=\alpha_{i}+\rho_{1} \text { treatment }_{i} * \text { post }_{t}+\rho x_{i t}^{T}+\epsilon_{1} \\
& \text { lnex }_{i t}^{\tau}\left(\tau \mid x_{i t}\right)=\alpha_{i}+\rho_{1} \text { treatment }_{i} * \text { post }_{t}+\rho x_{i t}^{T}+\epsilon_{1}
\end{aligned}
$$

By regression using different quantiles of independent variables, as shown in Table 4, when China's imports to the United States were analyzed by a control group of friction between China and the United States in the top 0.1 quantile of the sample (developing countries), China's imports to the United States were reduced by 36.5 percent, in the top 0.1 quartile countries, the country spillover effect is the largest, with the increasing number of quartile countries, the import spillover effect shows a decreasing trend, which shows that when sino-us trade friction, the trade transfer is more obvious in developing countries, moreover, the import spillover effect of trade transfer in developing countries is greater than that in developed countries.

Table 4. Import quantile regression for different country fractions.

\begin{tabular}{|c|c|c|c|c|c|c|c|c|c|}
\hline Variable & $\mathbf{0 . 1}$ & $\mathbf{0 . 2}$ & $\mathbf{0 . 3}$ & $\mathbf{0 . 4}$ & $\mathbf{0 . 5}$ & $\mathbf{0 . 6}$ & $\mathbf{0 . 7}$ & $\mathbf{0 . 8}$ & $\mathbf{0 . 9}$ \\
\hline \multirow{2}{*}{$\operatorname{did}$} & $-0.365^{* * *}$ & $-0.352 * * *$ & $-0.344^{* * *}$ & $-0.337 * * *$ & $-0.327 * * *$ & $-0.318^{* * *}$ & $-0.309 * * *$ & $-0.300^{* * *}$ & $-0.290^{* * *}$ \\
\cline { 2 - 10 } & $(-6.38)$ & $(-7.88)$ & $(-9.13)$ & $(-10.19)$ & $(-10.61)$ & $(-9.61)$ & $(-7.92)$ & $(-6.39)$ & $(-5.09)$ \\
\hline CountryFE & YES & YES & YES & YES & YES & YES & YES & YES & YES \\
\hline Time FE & YES & YES & YES & YES & YES & YES & YES & YES & YES \\
\hline
\end{tabular}

\section{Conclusions and policy recommendations}

\subsection{Conclusion}

By using the monthly data of import and export volume between China and its major trading partners from January 2014 to December 2019, The trade diversion effect of developing countries is greater than that of developed countries. The change of China's import and export to the United States is affected by the trade friction, the import is bigger than the export, which shows that China's export is less affected by the trade friction between China and the United States, but the real impact on China is the import from the United States. Secondly, by analyzing the heterogeneity of trade conflicts between China and the United States in different countries, developing countries benefit most in the context of trade conflicts between China and the United States, with both import and export increasing significantly and the impact lasting longer, while developed countries benefit in the short term, the long-term effects were not significant.

\subsection{Policy}

\subsubsection{Multilateral cooperation to improve value chain cooperation}

We should grasp the changing trend of international economic environment, adjust the development strategy of economy and trade in time, deal well with the trade relations with the United States, and adopt a more balanced strategy in dealing with the relations between external demand and domestic demand. We must respond positively, carry on the counter-reaction in the reasonable scope, in the short term, may pass the renminbi depreciation to ease the impact which the trade friction brings. In the long run, China needs to strengthen its scientific and technological innovation. We need to make breakthroughs in technologies that the United States has blocked, avoid the United States'scientific and technological blockade, strengthen China's breakthroughs in high-tech fields, and pay attention to the innovation of basic theories, innovation should be strengthened in areas of import and technological knowledge where there is no advantage. 


\subsubsection{Industrial transformation and upgrading as a result of national policies}

China should continue to build "Belt and Road", open wider to the outside world and raise the level of overseas investment. To increase the level of investment in developing countries in order to cushion the impact of sino-us trade conflicts on China's exports, and to increase the level of investment in developed countries in order to benefit China's imports and learn advanced technology and management experience, improving the competitiveness of Chinese enterprises. We will actively build multilateral cooperation organizations, strengthen multilateral cooperation under ASEAN, the European Union and RCEP, actively foster emerging markets, reduce reliance on specific groups or regions.

\section{References}

1. Gilbert Chan. Economic effect analysis of sino-us trade friction based on dynamic CGE model [ $\mathrm{J}]$. World Economic Research, (08) : 103-117 + 136.

2. Xiao Zhimin, Feng Shenghao. (2019) economic impact analysis of sino-us trade frictions: a valueadded trade perspective $[\mathrm{J}]$. International Trade and economic exploration, 35(01) : 55-69.

3. Lu Yue, Lou Chengrong, Du Yingxin, Tu Xinquan. (2019) trade friction effect analysis based on sino-us tariff list [J] . Financial Research, 45(02) : 59-72.

4. Cao Ping, Xiao Shengpeng, Lin Changqing. (2021) re-evaluation of the innovation effect of American anti-dumping against China on Chinese enterprises. International Trade and economic exploration, $37(01): 34-49$.

5. Cui Lianbiao, Zhu Lei, Song Malin, Zheng Haitao. (2018) International economic impact assessment of china-us trade frictions $[\mathrm{J}]$. Financial Research, $44(12): 4-17$. 